\section{PENYELENGGARAAN KEDAULATAN NEGARA ATAS WILAYAH UDARA NEGARA KESATUAN REPUBLIK INDONESIA ${ }^{1}$ \\ Oleh: Ivena J. A. Sangkay ${ }^{2}$ \\ Hengky A. Korompis ${ }^{3}$ \\ Youla O. Aguw ${ }^{4}$}

\begin{abstract}
Abstrak
Penelitian ini dilakukan dengan tujuan untuk
\end{abstract} mengetahui bagaimana pengaturan hukum mengenai penyelenggaraan kedaulatan negara atas wilayah udara Negara Kesatuan Republik Indonesia dan bagaimana sanksi hukum apabila melakukan pelanggaran atas larangan dalam penyelenggaraan kedaulatan negara atas wilayah udara Negara Kesatuan Republik Indonesia. Dengan menggunakan metode penelitian yuridis normatif, disimpulkan: 1. Pengaturan hukum mengenai penyelenggaraan kedaulatan negara atas wilayah udara Negara Kesatuan Republik Indonesia menunjukkan Negara Kesatuan Republik Indonesia berdaulat penuh dan eksklusif atas wilayah udara Republik Indonesia. Dalam rangka penyelenggaraan kedaulatan negara atas wilayah udara Negara Kesatuan Republik Indonesia, Pemerintah melaksanakan wewenang dan tanggung jawab pengaturan ruang udara untuk kepentingan penerbangan, perekonomian nasional, pertahanan dan keamanan negara, sosial budaya, serta lingkungan udara. Pemerintah menetapkan kawasan udara terlarang dan terbatas. Pesawat udara Indonesia atau pesawat udara asing dilarang terbang melalui kawasan udara terlarang. Larangan terbang sebagaimana dimaksud bersifat permanen dan menyeluruh. Kawasan udara terbatas hanya dapat digunakan untuk penerbangan pesawat udara negara. 2 . Sanksi hukum apabila melakukan pelanggaran atas larangan dalam penyelenggaraan kedaulatan negara atas wilayah udara Negara Kesatuan Republik Indonesia dapat diberlakukan ketentuan pidana terhadap setiap orang yang mengoperasikan pesawat udara Indonesia atau pesawat udara asing yang memasuki kawasan udara terlarang sebagaimana dimaksud dalam Pasal 7 ayat (2)

\footnotetext{
${ }^{1}$ Artikel Skripsi

2 Mahasiswa pada Fakultas Hukum Unsrat

${ }^{3}$ Fakultas Hukum Unsrat, Magister Ilmu Hukum

${ }^{4}$ Fakultas Hukum Unsrat, Doktor Ilmu Hukum
}

dipidana dengan pidana penjara paling lama 8 (delapan) tahun dan denda paling banyak Rp500.000.000,00 (lima ratus juta rupiah) dan setiap orang yang mengoperasikan pesawat udara Indonesia atau pesawat udara asing yang memasuki kawasan udara terbatas sebagaimana dimaksud dalam Pasal 7 ayat (4) dipidana dengan pidana penjara paling lama 3 (tiga) tahun atau denda paling banyak Rp500.000.000,00 (lima ratus juta rupiah).

Kata kunci: Penyelenggaraan Kedaulatan Negara, Wilayah Udara, Negara Kesatuan Republik Indonesia

\section{PENDAHULUAN}

\section{A. Latar Belakang}

Pemanfaatan wilayah udara merupakan implementasi dari kedaulatan Negara Republik Indonesia yang utuh dan eksklusif atas ruang udaranya, yang memuat tatanan ruang udara nasional, penyelenggaraan pelayanan, personel dan fasilitas navigasi penerbangan, serta pengaturan tentang tata cara navigasi, komunikasi penerbangan, pengamatan dan larangan mengganggu pelayanan navigasi penerbangan, termasuk pemberian sanksi.

Tatanan ruang udara nasional ditetapkan untuk mewujudkan penyelenggaraan pelayanan navigasi penerbangan yang andal dalam rangka keselamatan penerbangan dengan mengacu pada peraturan nasional dan regulasi Organisasi Penerbangan Sipil Internasional (International Civil Aviation Organisation/ICAO) yang terkait dengan penetapan dan penggunaan ruang udara. Dalam penggunaan ruang udara tersebut, diberikan pelayanan oleh Pemerintah selaku penyelenggara pelayanan navigasi penerbangan, terdiri atas pelayanan lalu lintas penerbangan, komunikasi penerbangan, informasi aeronautika, informasi meteorologi penerbangan, serta informasi pencarian dan pertolongan. Guna mendukung kelancaran kegiatan penerbangan serta keselamatan penerbangan, penyelenggara pelayanan navigasi penerbangan menyiapkan personel yang kompeten, memasang dan mengoperasikan serta merawat fasilitas navigasi penerbangan. ${ }^{5}$

\footnotetext{
5 Penjelasan Atas Undang-Undang Nomor 1 Tahun 2009 tentang Penerbangan.
} 
Untuk menjamin terwujudnya penyelenggaraan penerbangan yang memenuhi standar keselamatan dan keamanan, UndangUndang ini mengatur penetapan program keselamatan penerbangan nasional, program keamanan penerbangan nasional, dan program budaya tindakan keselamatan yang mengacu pada regulasi Organisasi Penerbangan Sipil Internasional (ICAO). Program keselamatan penerbangan nasional memuat peraturan keselamatan, sasaran keselamatan, sistem pelaporan keselamatan, analisis data dan pertukaran informasi keselamatan (safety data analysis and exchange), kegiatan investigasi kecelakaan dan kejadian (accident and incident investigation), promosi keselamatan (safety promotion), pengawasan keselamatan (safety oversight), dan penegakan hukum (law enforcement). Sedangkan program keamanan penerbangan nasional memuat peraturan keamanan, sasaran keamanan, personel keamanan, pembagian tanggung jawab keamanan, perlindungan bandar udara, pesawat udara, dan fasilitas navigasi, pengendalian dan penjaminan keamanan terhadap orang dan barang di pesawat udara, penanggulangan tindakan melawan hukum, penyesuaian sistem keamanan terhadap tingkat ancaman keamanan, dan pengawasan keamanan penerbangan. ${ }^{6}$

Indonesia sebagai negara kepulauan memiliki garis perbatasan dengan setidaknya enam negara yaitu Australia, Papua Nugini, Filipina, Singapura, Malaysia dan Tiongkok (Cina). Dengan segala keterbatasan sumber daya manusia dan peralatan untuk memantau wilayah perbatasan, maka kerap kali terjadi pelanggaran wilayah perbatasan Indonesia oleh beberapa pihak yang tidak bertanggung jawab. Di wilayah udara Indonesia sendiri sering terjadi pelanggaran oleh pesawat udara asing tidak berizin atau lebih dikenal dengan istilah black flight. Pelanggaran semacam ini seharusnya ditindak secara tegas serta tidak dapat ditolerir karena mengancam kedaulatan kita sebagai suatu bangsa. Pasal 1 Konvensi Chicago Tahun 1944 secara tegas menyatakan bahwa semua negara mempunyai suatu kedaulatan yang utuh dan komplit/penuh (complete and exclusive sovereignity) atas ruang udara dalam wilayah

\footnotetext{
${ }^{6}$ Penjelasan Atas Undang-Undang Nomor 1 Tahun 2009
} tentang Penerbangan. kedaulatannya. Istilah complete and exclusive sovereignty mengandung arti bahwa kedaulatan di udara adalah penuh dan eksklusif. Kedaulatan yang penuh adalah kedaulatan yang mutlak, sedangkan kedaulatan yang eksklusif adalah hak negara untuk memanfaatkan dan mengatur ruang udaranya. ${ }^{72}$

\section{B. Rumusan Masalah}

1. Bagaimanakah pengaturan hukum mengenai penyelenggaraan kedaulatan negara atas wilayah udara Negara Kesatuan Republik Indonesia?

2. Bagaimanakah sanksi hukum apabila melakukan pelanggaran atas larangan dalam penyelenggaraan kedaulatan negara atas wilayah udara Negara Kesatuan Republik Indonesia?

\section{Metode Penelitian}

Metode penelitian hukum yang digunakan untuk penyusunan penulisan ini ialah metode penelitian hukum normatif. Bahan-bahan hukum yang digunakan terdiri dari: bahan hukum primer ialah: peraturan perundangundangan di bidang penerbangan dan bahan hukum sekunder terdiri dari literatur-literatur, jurnal hukum dan artikel hukum, yang sesuai dengan materi penulisan. Bahan-bahan hukum tersier seperti kamus umum dan kamus hukum. Bahan-bahan hukum primer dan sekunder dianalisis secara normatif kualitatif.

\section{PEMBAHASAN}

\section{A. Pengaturan Hukum Mengenai Penyelenggaraan Kedaulatan Negara Atas Wilayah Udara Negara Kesatuan Republik Indonesia}

Sesuai Konvensi Chicago Tahun 1944, dalam Pasal 1 dinyatakan bahwa setiap negara mempunyai kedaulatan yang utuh dan penuh (complete and exclusive souvereignity) atas ruang udara atas wilayah kedaulatannya. Dari Pasal tersebut memberikan pandangan bahwa perwujudan dari kedaulatan yang penuh dan

\footnotetext{
${ }^{7}$ Danang Risdiarto. Kendala Hukum Penindakan Terhadap Pesawat Udara Sipil Asing Tidak Berizin Yang Memasuki Wilayah Udara Indonesia. Jurnal Legislasi Indonesia. Vol. 16 No. 3-September 2019: 353-368. hlm. 354. (Lihat Priyatna Abdurrasyid. Kedaulatan Negara di Ruang Udara. Fikahati Aneska. Jakarta. 2003. hlm. 161-162).
} 
utuh atas ruang udara diatas wilayah teritorial, adalah: Setiap negara berhak mengelola dan mengendalikan secara penuh dan utuh atas ruang udara nasionalnya; Tidak satupun kegiatan atau usaha diruang udara nasional tanpa mendapatkan izin terlebih dahulu atau sebagaimana telah diatur dalam suatu perjanjian udara antara negara dengan negara lain baik secara bilateral maupun multilateral. ${ }^{8}$

Indonesia mempunyai wilayah kedaulatan atas ruang udara nasional sebagaimana ditetapkan dalam Pasal 5 dan Pasal 6 UU No. 1 Tahun 2009 tentang Penerbangan. Kegiatan penerbangan merupakan salah satu wujud kegiatan dan atau usaha terhadap wilayah kedaulatan atas wilayah udara yang diberi wewenang dan tanggung jawab kepada Pemerintah sebagaimana ditetapkan dalam Pasal tersebut bahwa dalam rangka penyelenggaraan kedaulatan negara atas wilayah udara Republik Indonesia Pemerintah melaksanakan wewenang dan tanggung jawab pengaturan ruang udara untuk kepentingan pertahanan dan keamanan negara, penerbangan dan ekonomi nasional. ${ }^{9}$

Undang-Undang Nomor 1 Tahun 2009 Tentang Penerbangan, mengatur dalam Pasal 5. Negara Kesatuan Republik Indonesia berdaulat penuh dan eksklusif atas wilayah udara Republik Indonesia.

Pasal 6. Dalam rangka penyelenggaraan kedaulatan negara atas wilayah udara Negara Kesatuan Republik Indonesia, Pemerintah melaksanakan wewenang dan tanggung jawab pengaturan ruang udara untuk kepentingan penerbangan, perekonomian nasional, pertahanan dan keamanan negara, sosial budaya, serta lingkungan udara.

Pasal 7 ayat:

(1) Dalam rangka melaksanakan tanggung jawab sebagaimana dimaksud dalam Pasal 6, Pemerintah menetapkan kawasan udara terlarang dan terbatas.

(2) Pesawat udara Indonesia atau pesawat udara asing dilarang terbang melalui kawasan udara terlarang.

(3) Larangan terbang sebagaimana dimaksud pada ayat (2) bersifat permanen dan menyeluruh.

\footnotetext{
${ }^{8}$ Nurlely Darwis. Op.Cit. hlm. 73.

${ }^{9}$ Ibid. hlm. 73-74.
}

(4) Kawasan udara terbatas sebagaimana dimaksud pada ayat (1) hanya dapat digunakan untuk penerbangan pesawat udara negara.

Pasal 8 ayat:

(1) Pesawat udara yang melanggar wilayah kedaulatan Negara Kesatuan Republik Indonesia sebagaimana dimaksud dalam Pasal 5 diperingatkan dan diperintahkan untuk meninggalkan wilayah tersebut oleh personel pemandu lalu lintas penerbangan.

(2) Pesawat udara yang akan dan telah memasuki kawasan udara terlarang dan terbatas sebagaimana dimaksud dalam Pasal 7 ayat (2) dan ayat (4) diperingatkan dan diperintahkan untuk meninggalkan wilayah tersebut oleh personel pemandu lalu lintas penerbangan.

(3) Personel pemandu lalu lintas penerbangan wajib menginformasikan pesawat udara yang melanggar wilayah kedaulatan dan kawasan udara terlarang dan terbatas sebagaimana dimaksud pada ayat (1) dan ayat (2) kepada aparat yang tugas dan tanggung jawabnya di bidang pertahanan negara.

(4) Dalam hal peringatan dan perintah sebagaimana dimaksud pada ayat (1) dan ayat (2) tidak ditaati, dilakukan tindakan pemaksaan oleh pesawat udara negara untuk keluar wilayah Negara Kesatuan Republik Indonesia atau kawasan udara terlarang dan terbatas atau untuk mendarat di pangkalan udara atau bandar udara tertentu di dalam wilayah Negara Kesatuan Republik Indonesia.

(5) Personel pesawat udara, pesawat udara, dan seluruh muatannya yang melanggar ketentuan sebagaimana dimaksud pada ayat (1) dan ayat (2), diperiksa dan disidik sesuai dengan ketentuan perundangundangan.

Pasal 9. Ketentuan lebih lanjut mengenai pelanggaran wilayah kedaulatan, penetapan kawasan udara terlarang, kawasan udara terbatas, pelaksanaan tindakan terhadap pesawat udara dan personel pesawat udara, serta tata cara dan prosedur pelaksanaan tindakan pemaksaan oleh pesawat udara negara diatur dengan Peraturan Pemerintah. 
Kedaulatan negara merupakan salah satu hal yang sangat penting untuk dijaga oleh suatu negara. Sebagaimana diketahui dalam literatur ketatanegaraan, bahwa syarat berdirinya suatu negara adalah adanya wilayah, rakyat dan pemerintahan yang berdaulat. Negara yang berdaulat diartikan sebagai negara yang mempunyai kekuasaan tertinggi (supreme authority) yang berarti bebas dari kekuasaan negara lain, bebas dalam arti seluas-luasnya baik ke dalam maupun ke luar. ${ }^{10}$ Pengakuan dunia internasional akan wilayah udara sebagai bagian dari kedaulatan negara memberikan legitimasi yang kuat bagi Indonesia sebagai suatu negara yang luas. Wilayah udara adalah ruang udara yang berada di atas wilayah daratan dan perairan suatu negara.

Wilayah suatu negara biasanya terdiri dari tiga dimensi, yaitu daratan, perairan, dan ruang udara. Namun tidak semua negara memiliki wilayah perairan (laut) atau dikatakan sebagai negara dua dimensi, seperti Laos, Kamboja, Nepal, Kazakhstan, Swiss, Austria, Irak, Congo, Nigeria, dan lain sebagainya, yang dalam istilah hukum internasional disebut landlocked states. Sedangkan yang memiliki lengkap tiga dimensi, yaitu Indonesia, Singapura, Malaysia, Filipina, India, Pakistan, Inggris, Belanda, Amerika Serikat, Kanada, Argentina, China, Korea, Jepang, dan lain sebagainya. ${ }^{11}$

\section{B. Sanksi Hukum Apabila Melakukan Pelanggaran Atas Larangan Dalam Penyelenggaraan Kedaulatan Negara Atas Wilayah Udara Negara Kesatuan Republik Indonesia}

Dari reportase Republika tanggal 13 Nopember 2014, pelanggaran atas wilayah Indonesia tercatat pertama kali terjadi pada tanggal 2 Juli 2003 ketika lima pesawat militer F-18 Hornet milik Amerika Serikat melintasi pulau Bawean tanpa izin. Pesawat temput TNIAU kita lalu mengejar dan memperingatkan

\footnotetext{
${ }^{10}$ Baiq Setiani. Konsep Kedaulatan Negara di Ruang Udara dan Upaya Penegakan Pelanggaran Kedaulatan oleh Pesawat Udara Asing (State Sovereignty over the Airspace Concept and Enforcement Efforts of Sovereignty Violations by Foreign Aircraft). Jurnal Konstitusi Vol. 14. No. 3.September 2017. hlm. 491.

${ }^{11}$ /bid. hlm. 491. (Lihat E. Saefullah Wiradipradja, "Wilayah Udara Negara Ditinjau dari Segi Hukum Internasional", Indonesia Journal of International Law Vol. 6 No. 4, 2009, hlm. 498-499).
}

mereka hingga pergi keluar dari udara Indonesia. Sembilan tahun kemudian, pada bulan Juni 2011 pesawat angkut C17 Globe Master pernah masuk ke wilayah Indonesia tanpa izin. Pesawat angkut raksasa itu masuk lewat Pekanbaru, Riau. Pesawat dihalau keluar hingga ke Morotai. Kemudian pada tanggal 29 November 2012, pesawat sipil yang berisi wakil Perdana Menteri Papua Nugini dikawal ketat oleh pesawat militer TNI-AU selama 37 menit karena melintas tanpa izin. Namun, tidak ada aksi menurunkan secara paksa dan pesawat itu dibiarkan terbang kembali. Pada tahun yang sama, tepatnya tanggal 30 September 2012 Pilot Cessna 208 berkebangsaan Amerika Serikat, Michael A. Byod, melintas tanpa izin di wilayah udara Indonesia, kemudian dipaksa untuk mendarat di bandara Sepinggan Balikpapan, Kalimantan Timur. ${ }^{12}$

Pelanggaran izin melintas terjadi empat kali pada tahun 2014. Pesawat asing melintas di Sumatera Utara. Pertama, pesawat yang hanya berisi satu pilot asal Swedia itu dipaksa turun di Lanud Soewondo Medan (14 April 2014). Kedua, pesawat asing yang diawaki dua pilot asal Australia terbang tanpa izin di Manado dan dipaksa turun ke Lanud Sam Ratulangi, Manado (22 Oktober 2014). Ketiga, satu pesawat militer Singapura dipaksa mendarat di Lanud Supadio, Pontianak, saat melintas wilayah Kalimantan (28 Oktober 2014). Dan terakhir, satu pesawat Saudi Arabia Airlines dipaksa mendarat di Bandara El Tari, Kupang (3 November 2014). ${ }^{13}$

Pada dewasa ini, hampir dapat dipastikan bahwa semua jenis atau bentuk kejahatan tidak lagi dapat hanya dipandang sebagai yurisdiksi kriminal satu negara, akan tetapi sering diklaim termasuk yurisdiksi kriminal lebih dari satu atau dua negara sehingga dalam perkembangannya, kemudian telah menimbulkan masalah konflik yurisdiksi yang sangat mengganggu hubungan internasional antarnegara yang berkepentingan di dalam kasus tindak pidana tertentu yang bersifat lintas batas territorial. Masyarakat internasional yang tergabung dalam wadah Perserikatan Bangsa-Bangsa mengakui bahwa perkembangan tindak pidana lintas batas antarnegara dalam upaya pencegahan dan

\footnotetext{
12 Ibid. hlm. 501.

13/bid. hlm. 501.
} 
pemberantasannya terutama jika dalam tindak pidana tersebut terlibat warga negara asing. ${ }^{14}$

Dalam hal ini terjadinya kejahatan itu mungkin di wilayah negara lain atau di suatu tempat di luar wilayah negara, seperti telah dikemukakan di atas dan atas kejahatan tersebut ada kepentingan nasional dari suatu negara atau lebih yang terkait dengan kejahatan itu, misalnya kejahatan itu menimbulkan korban di dalam wilayahnya atau yang menjadi korban adalah warganegaranya sendiri ataupun korban-korban lain yang pada dasarnya merugikan negara yang bersangkutan, negara itu tentu saja berkepentingan untuk mengaturnya di dalam hukum atau peraturan perundang-undangan pidana nasionalnya, menerapkannya terhadap si pelakunya serta mengadili dan jika terbukti bersalah selanjutnya adalah menghukum dan mengeksekusinya di dalam wilayahnya sendiri. ${ }^{15}$

Undang-Undang Nomor 1 Tahun 2009 Tentang Penerbangan. Pasal 401. Setiap orang yang mengoperasikan pesawat udara Indonesia atau pesawat udara asing yang memasuki kawasan udara terlarang sebagaimana dimaksud dalam Pasal 7 ayat (2) dipidana dengan pidana penjara paling lama 8 (delapan) tahun dan denda paling banyak Rp500.000.000,00 (lima ratus juta rupiah).

Pasal 402. Setiap orang yang mengoperasikan pesawat udara Indonesia atau pesawat udara asing yang memasuki kawasan udara terbatas sebagaimana dimaksud dalam Pasal 7 ayat (4) dipidana dengan pidana penjara paling lama 3 (tiga) tahun atau denda paling banyak Rp500.000.000,00 (lima ratus juta rupiah).

Dalam Konvensi Chicago 1944, zona larangan terbang atau prohibited area diatur di dalam Pasal 9 Konvensi Chicago 1944. Konvensi ini memberikan kewenangan kepada negara dalam menetapkan wilayah yang boleh dan tidaknya dilalui pesawat terbang. Agar tidak adanya kesewenangan dari tindakan suatu negara, Konvensi Chicago memberikan batasan terhadap alasan apa yang boleh dijadikan sebagai wilayah udara suatu negara tersebut

\footnotetext{
${ }^{14}$ Romli Atmasasmita, Pengantar Hukum Pidana Internasional, Refika Aditama, Cetakan, Pertama. Bandung. 2000, hlm. 5.

15. Wayan Parthiana, Hukum Pidana Internasional, Cet. I. Yrama Widya, Bandung, 2006, hlm. 31-30.
}

terbatas dan/atau terlarang. Zona larangan di bentuk demi menjaga keamanan dan pertahanan suatu negara dan juga demi keselamatan penerbangan. Zona larangan terbang dapat diterapkan kepada daerah konflik ataupun daerah non konflik. Penerapan zona larangan terbang juga harus disesuaikan dengan sewajar mungkin agar tidak mengganggu navigasi penerbangan dan sesegera mungkin di umumkan kepada negara lain dan juga kepada organisasi penerbangan sipil internasional. ${ }^{16}$

Penerapan zona larangan terbang dapat diterapkan di kawasan terlarang dan kawasan berbahaya. Menurut Pasal di atas bahwa zona larangan terbang dapat berubah-ubah, jika ditetapkan dalam keadaan darurat seperti jika suatu negara sedang terjadi konflik perang atau wilayah tersebut merupakan daerah rawan bencana yang dapat menimbulkan kerusakan pada navigasi penerbangan. Pada intinya zona larangan di tetapkan sebagai bentuk perlindungan terhadap pesawat udara terutama pesawat sipil. ${ }^{17}$

Zona larangan terbang juga disebut di dalam Peraturan Pemerintah Nomor 3 Tahun 2001 tentang Keamanan dan Keselamatan. Pengaturan zona terlarang atau di dalam peraturan pemerintah ini disebut sebagai kawasan udara terlarang diatur dalam Pasal 1 angka 10. Wilayah udara Indonesia dibagi ke dalam 3 bentuk kategori, yaitu kawasan berbahaya (danger), kawasan terlarang (prohibited), dan kawasan terbatas (restricted). Kawasan berbahaya (danger) diartikan sebagai ruang udara tertentu di atas daratan dan/atau perairan, yang sewaktuwaktu dapat terjadi aktivitas yang membahayakan penerbangan pesawat udara. Kawasan terlarang (prohibited) diartikan sebagai sebuah wilayah udara di atas daratan dan/atau perairan teritorial suatu Negara, di mana pesawat udara dilarang terbang melalui ruang udara tersebut karena pertimbangan pertahanan dan keamanan negara serta keselamatan penerbangan. Kawasan terbatas (restricted) diartikan ruang udara tertentu di atas daratan dan/atau perairan, karena pertimbangan pertahanan dan

\footnotetext{
${ }^{16}$ Silmiwati. Penegakan Hukum Terhadap Zona Larangan Terbang Bagi Pesawat Sipil Asing Di Indonesia. UBELAJ, Volume 2 Number 2, Oktober 2017.hIm. 127.

$17 \mathrm{lbid}$. hlm. 127.
} 
keamanan atau keselamatan penerbangan atau kepentingan umum, berlaku pembatasan penerbangan bagi pesawat udara yang terbang melalui ruang udara tersebut. ${ }^{18}$

Perbedaan dari ketiga kawasan tersebut ialah dapat dilihat dalam penggunaannya, kawasan berbahaya digunakan ketika terdapat potensi bahaya untuk penerbangan, yang sewaktu-waktu dapat berubah-ubah, sebagai contoh kawasan gunung berapi aktif. Sedangkan kawasan terlarang digunakan untuk kepentingan keamanan dan pertahanan negara yang mana benar-benar dilarang untuk penerbangan pesawat sipil serta penetapan ini bersifat permanen dan menyeluruh bagi pesawat sipil nasional dan pesawat sipil asing, larangan tersebut hanya dapat ditetapkan di dalam wilayah udara Indonesia, sebagai contoh instalasi nuklir, istana Presiden dan pangkalan militer. Dan untuk kawasan terbatas, kawasan udara dengan pembatasan bersifat tidak tetap dan hanya dapat digunakan untuk operasi penerbangan tertentu seperti pesawat udara TNI. Pada waktu tidak digunakan atau tidak aktif, kawasan ini dapat digunakan untuk penerbangan sipil. Pembatasan dapat berupa pembatasan ketinggian dan hanya dapat ditetapkan di dalam wilayah udara Indonesia, misalnya instalasi atau area pelatihan militer. ${ }^{19}$

Penetapan kawasan tersebut diatas didasarkan pada AIP (Aeronautical Information Publication) Indonesia bagian Enr 5 Navigation Warning. Dalam AIP Indonesia, daerah yang dijadikan sebagai kawasan tersebut diberikan kode, untuk kawasan terlarang dengan kode $P$, kawasan terbatas dengan kode $R$, dan kawasan berbahaya dengan kode $D$. Dalam pengawasannya, ketiga kawasan tersebut diawasi oleh Air Controller yang berada di Pusat yaitu di Jakarta dan Air Controller yang berada di Makassar, sehingga untuk membedakan pengawasannya, AIP memberikan kode WI untuk wilayah pengawasan sektor Jakarta dan WA untuk wilayah pengawasan sektor Makassar. ${ }^{20}$

\footnotetext{
$18 \mathrm{lbid}$. hlm. 128.

${ }^{19} / \mathrm{bid}$. hlm. 128.

${ }^{20} /$ bid. hlm. 128-129. Aeronautical Information Publication merupakan publikasi yang dikeluarkan oleh atau dengan otoritas Negara dan berisi informasi aeronautika untuk kepentingan navigasi udara.
}

Setelah memperhatikan dan mempelajari sejumlah insiden-insiden pelanggaran izin masuk pesawat asing ke wilayah udara Indonesia dapat diindentifikasikan bahwamasalahnya bermuara kepada tiga hal. Pertama, pesawat negara-negara tetangga sering kali melanggar wilayah udara Indonesia mendalilkan atau mendasarkan bahwa yang melanggar bukan pilot yang mengemudikannya, tetapi oleh operator pesawat dari maskapai yang bersangkutan dalam kedudukan sebagai pemilik pesawat tersebut. Hal ini, karena pilot hanyalah yang menjalankan perintah untuk mengemudikan pesawat. Konsekuensi dari masalah ini berakibat kepada sulitnya menjatuhkan sanksi kepada personal, karena pihak operatornya adalah badan hukum asing yang berada di luar yurisdiksi dan wilayah teritorial Indonesia. ${ }^{21}$

Kedua, sanksi denda yang terlalu kecil yaitu Rp 60 juta terhadap pelanggaran atas wilayah udara di Indonesia oleh pesawat asing, meskipun ancaman hukuman Pasal 414 Undang-Undang Nomor 1 Tahun 2009 tentang Penerbangan sesungguhnya cukup tinggi. Pasal tersebut berbunyi bahwa setiap orang yang mengoperasikan pesawat udara asing di wilayah Negara RI tanpa izin Menteri sebagaimana dimaksud dalam Pasal 63 ayat (2) UU ini dapat dipidana dengan pidana penjara paling lama 5 tahun atau denda paling banyak Rp 2 miliar rupiah. Artinya yang terjadi di lapangan adalah sanksi denda yang tidak maksimal di dalam menjatuhkan hukumannya. Sementara itu, biaya operasional pesawat Sukhoi yang harus dikeluarkan TNI AU dalam rangka melakukan pengejaran pesawat asing menghabiskan anggaran yang sangat besar. Artinya, terjadi ketidakseimbangan antara biaya operasional pesawat TNI AU dengan sanksi yang dijatuhkan Kementerian Perhubungan. ${ }^{22}$

Ketiga, kewenangan penyidikan untuk penanganan perkara pelanggaran izin pesawat terbang asing yang melintasi wilayah Indonesia adalah PPNS dari Kementerian Perhubungan sesuai dengan Pasal 399 dan 400 dari UndangUndang Nomor 1 Tahun 2009 tentang Penerbangan. Ketentuan ini mempersulit di dalam penanganannya, karena TNI AU yang melakukan pengejaran, sementara

${ }^{21}$ Danang Risdiarto. Op.Cit. hlm. 86.

22 Ibid. hlm. 86-87. 
hukumannya diberikan oleh Kementerian Perhubungan. Hal ini berarti ada dualisme penanganannya, sehingga terbuka perbedaan menghadapi dan menyelesaikan permasalahan ini. ${ }^{23}$

Pada dewasa ini, hampir dapat dipastikan bahwa semua jenis atau bentuk kejahatan tidak lagi dapat hanya dipandang sebagai yurisdiksi kriminal satu negara, akan tetapi sering diklaim termasuk yurisdiksi kriminal lebih dari satu atau dua negara sehingga dalam perkembangannya, kemudian telah menimbulkan masalah konflik yurisdiksi yang sangat mengganggu hubungan internasional antarnegara yang berkepentingan di dalam kasus tindak pidana tertentu yang bersifat lintas batas territorial. Masyarakat internasional yang tergabung dalam wadah Perserikatan Bangsa-Bangsa mengakui bahwa perkembangan tindak pidana lintas batas antarnegara dalam upaya pencegahan dan pemberantasannya terutama jika dalam tindak pidana tersebut terlibat warga negara asing. ${ }^{24}$

Pengaturan hukum mengenai penyelenggaraan kedaulatan negara atas wilayah udara Negara Kesatuan Republik Indonesia dimaksudkan untuk menjamin adanya kepastian hukum bagi Negara Kesatuan Republik Indonesia untuk melakukan penegakan hukum di atas wilayah udara apabila terjadi pelanggaran hukum. Sanksi hukum dapat diberlakukan apabila terjadi pelanggaran atas larangan dalam penyelenggaraan kedaulatan negara atas wilayah udara Negara Kesatuan Republik Indonesia.

\section{PENUTUP}

\section{A. Kesimpulan}

1. Pengaturan hukum mengenai penyelenggaraan kedaulatan negara atas wilayah udara Negara Kesatuan Republik Indonesia menunjukkan Negara Kesatuan Republik Indonesia berdaulat penuh dan eksklusif atas wilayah udara Republik Indonesia. Dalam rangka penyelenggaraan kedaulatan negara atas wilayah udara Negara Kesatuan Republik Indonesia, Pemerintah melaksanakan wewenang dan tanggung jawab pengaturan ruang udara untuk kepentingan penerbangan,

\footnotetext{
${ }^{23} \mathrm{Ibid}$. hlm. 87.

${ }^{24}$ Romli Atmasasmita, Op.Cit. hlm. 5.
}

perekonomian nasional, pertahanan dan keamanan negara, sosial budaya, serta lingkungan udara. Pemerintah menetapkan kawasan udara terlarang dan terbatas. Pesawat udara Indonesia atau pesawat udara asing dilarang terbang melalui kawasan udara terlarang. Larangan terbang sebagaimana dimaksud bersifat permanen dan menyeluruh. Kawasan udara terbatas hanya dapat digunakan untuk penerbangan pesawat udara negara.

2. Sanksi hukum apabila melakukan pelanggaran atas larangan dalam penyelenggaraan kedaulatan negara atas wilayah udara Negara Kesatuan Republik Indonesia dapat diberlakukan ketentuan pidana terhadap setiap orang yang mengoperasikan pesawat udara Indonesia atau pesawat udara asing yang memasuki kawasan udara terlarang sebagaimana dimaksud dalam Pasal 7 ayat (2) dipidana dengan pidana penjara paling lama 8 (delapan) tahun dan denda paling banyak Rp500.000.000,00 (lima ratus juta rupiah) dan setiap orang yang mengoperasikan pesawat udara Indonesia atau pesawat udara asing yang memasuki kawasan udara terbatas sebagaimana dimaksud dalam Pasal 7 ayat (4) dipidana dengan pidana penjara paling lama 3 (tiga) tahun atau denda paling banyak Rp500.000.000,00 (lima ratus juta rupiah).

\section{B. SARAN}

1. Pengaturan hukum mengenai penyelenggaraan kedaulatan negara atas wilayah udara Negara Kesatuan Republik Indonesia memerlukan upaya pengawasan yang efektif oleh pihak pemerintah Negara Kesatuan Republik Indonesia guna mencegah terjadinya pelanggaran hukum dalam penyelenggaraan kedaulatan negara atas wilayah udara Negara Kesatuan Republik Indonesia dan hal ini merupakan bagian dari penegakan hukum untuk menjaga kedaulatan negara atas wilayah udara Negara Kesatuan Republik Indonesia.

2. Sanksi hukum apabila melakukan pelanggaran atas larangan dalam penyelenggaraan kedaulatan negara atas 
wilayah udara Negara Kesatuan Republik Indonesia, perlu diterapkan sesuai dengan peraturan perundang-undangan yang berlaku untuk memberikan efek jera terhadap pelaku dan untuk kepentingan pencegahan merupakan suatu peringatan agar perbuatan yang sama tidak dilakukan lagi oleh pihak lain.

\section{DAFTAR PUSTAKA}

Adolf Huala, Aspek-Aspek Negara Dalam Hukum Internasional, Keni Media Bandung. 2011.

Atmasasmita Romli, Pengantar Hukum Pidana Internasional, Refika Aditama, Cetakan, Pertama. Bandung. 2000.

Atmasasmita Romli, Pengantar Hukum Pidana Internasional, Refika Aditama, Cetakan, Pertama. Bandung. 2000.

Bunga Alditya Gerald. Pelanggaran Kedaulatan Indonesia oleh Pesawat F-18 Hornet Milik Amerika Serikat (Ditinjau Dari Konvensi Chicago Tahun 1944 Dan Konvensi Hukum Laut Tahun 1982). Dialogia luridica: Jurnal Hukum Bisnis dan Invenstasi. Volume 8 No. 2. April 2017.

Darwis Nurlely.Wibawa Negara Kesatuan R.I Atas Kedaulatan Negara Wilayah Udara. Jurnal IImiah Hukum Dirgantara. Fakultas Hukum Universitas Suryadarma. Vol. 5. No. 1. September 2014.

Hamzah Andi, Terminologi Hukum Pidana, Sinar Grafika, Jakarta, 2008.

Hamzah Andi, Asas-Asas Hukum Pidana, Cetakan III. Edisi Revisi, PT. Rineka Cipta, Jakarta, 2008.

Huda Chairul, Dari "Tiada Pidana Tanpa Kesalahan Menuju Kepada "Tiada Pertanggungjawaban Pidana Tanpa Kesalahan (Tinjauan Kritis Terhadap Teori Pemisahan Tindak Pidana dan Pertanggungjawaban Pidana), Kencana, Jakarta, 2006.

Husna Lenny dan Agus Riyanto. Peran Pemerintah Dalam Upaya Pengambilalihan Flight Information Region (Fir) Singapura Atas Wilayah Udara Kepulauan Riau. Jurnal Cahaya Keadilan Volume 7 Nomor 2
Oktober 2019. ISSN: 2339-1693.ISSN (online): 2580-2461.

Kansil C.S.T., Christine S.T. Kansil, Engelien R. Palandeng dan Godlieb N. Mamahit, Kamus Istilah Aneka Hukum, Edisi Pertama, Cetakan Kedua, Jala Permata Aksara, Jakarta, 2010.

Likadja Frans, Masalah Lintas Di Ruang Udara, Binacipta, Bandung, 1987.

Marbun SF. Pokok-Pokok Hukum Administrasi Negara. Liberty. Yogyakarta. 1997.

Martono K., Hukum Udara, Angkutan Udara Dan Hukum Angkasa, Alumni, Bandung,1987.

Martono H.K. dan Amad Sudiro, Hukum Udara Nasional dan Internasional Publik (Public International and National Air Law). Ed. I. Cetakan ke-I. PT. RajaGrafindo, Jakarta, 2012.

Marpaung Leden, Asas-Teori-Praktik Hukum Pidana, Sinar Grafika. Cetakan Kedua, Jakarta, 2005.

Masriani Tiena Yulies, Pengantar Hukum Indonesia, Cetakan Kelima, Sinar Grafika, Jakarta. 2009.

Moeljatno, Azas-Azas Hukum Pidana, PT.Rineka Cipta, Jakarta. 2008.

Muhammad Abdulkadir, Arti Penting dan Strategis Multimoda Pengangkutan Niaga di Indonesia, Dalam Perspektif Hukum Bisnis Di Era Globalisasi Ekonomi, Penerbit Genta Press. Yogyakarta. 2007.

Ningrum Lestari, Usaha Perjalanan Wisata Dalam Perspektif Hukum Bisnis, Citra Aditya Bakti, Bandung. 2004.

Parthiana.W. I. Pengantar Hukum Internasional. Mandar Maju. Bandung. 1990.

Parthiana Wayan I., Hukum Pidana Internasional, Cet. I. Yrama Widya, Bandung, 2006.

Risdiarto Danang. Kendala Hukum Penindakan Terhadap Pesawat Udara Sipil Asing Tidak Berizin Yang Memasuki Wilayah Udara Indonesia. Jurnal Legislasi Indonesia. Vol. 16 No. 3September 2019: 353-368.

Risdiarto Danang.Penyidik Tni Angkatan Udara Dalam Kasus Pelanggaran Wilayah Udara Yurisdiksi Indonesia Oleh Pesawat Terbang 
Asing Tidak Terjadwal (Air Force Investigators in The Event of a Violation of Indonesia's Airspace Jurisdiction by Unscheduled Foreign Aircraft). Jurnal Legislasi Indonesia. Vol. 14 No. 1- Maret 2017.

Rudy May T., Hukum Internasional 1. Cetakan Ketiga, PT. Refika Aditama, Bandung. 2010.

Santoso Iman M., Perspektif Imigrasi, Perum Percetakan Negara Republik Indonesia. Jakarta. 2007.

Setiani Baiq. Konsep Kedaulatan Negara di Ruang Udara dan Upaya Penegakan Pelanggaran Kedaulatan oleh Pesawat Udara Asing (State Sovereignty over the Airspace Concept and Enforcement Efforts of Sovereignty Violations by Foreign Aircraft). Jurnal Konstitusi Vol. 14. No. 3.September 2017.

Silmiwati. Penegakan Hukum Terhadap Zona Larangan Terbang Bagi Pesawat Sipil Asing Di Indonesia. UBELAJ, Volume 2 Number 2, Oktober 2017.

Starke J. G., Pengantar Hukum Internasional,1. Judul Asli Introduction to International Law. (Pengarang) J.G. Starke Q.C. (Penerjemah) Bambang Iriana, Djajaatmadja, Edisi Kesepuluh, Sinar Grafika.Jakarta. 2010.

Sunarso Siswanto, Ekstradisi \& Bantuan Timbal Balik Dalam Masalah Pidana Instrumen Penegakan Hukum Pidana Internasional, Rineka Cipta, Jakarta. 2009.

Ukun Wahyudin, Deportasi Sebagai Instrumen Penegakan Hukum dan Kedaulatan Negara di Bidang Keimigrasian. PT. Adi Kencana Aji. Jakarta. 2004. 